\title{
THE SOLAR PV SYSTEMS PAYBACK EFFECT OF THE PRICE DECREASE OF COMMUNAL ELECTRIC PRICES AND OF THE INTEREST RATE DECREASE OF THE CENTRAL BANK
}

\author{
Henrik Zsiborács, Gábor Pintér, BÉla PÁlyi \\ University of Pannonia, Georgikon Faculty \\ Hungary-8360 16 Deák Ferenc Street Keszthely, Hungary \\ ifj.zsiboracs.henrik@gmail.com
}

\begin{abstract}
The energy is one of the most important needs of the humanity. One of its biggest challenge or danger is that the world's demand for energy continues to grow.

The aim of present study is to review the introduction of solar energy utilization, the economic determination of the return of crystalline solar photovoltaic systems in Hungary, the electricity price reductions for individuals and the change in the payback period. The effect of the changing investment cost to the payback period based on the changes in electricity price reductions and in central bank interest rate is written in this study. An important question is for a household: decide by or against a solar (PV) system.

The main direction of our recent research is the utilization of photovoltaic (PV) solar energy with crystalline solar systems. The research was carried out in solar-electric power plants extended from $1.5 \mathrm{kWp}$ to $10 \mathrm{kWp}$. The calculation of payback time was performed by dynamic indices.
\end{abstract}

Keywords: renewable energy for individuals, solar energy utilisation, dynamic indices

\section{INTRODUCTION}

The photovoltaics technology is involving the direct conversion of solar isolation into electricity using solar cells. The sunshine used by solar panels constitutes an unfailing energy resource but the oil, the uranium and the coal are the most widely used energy resources today. Basic problem at the photovoltaics technology is that the energy production depends on the weather and it is necessary to use energy storages, which considerably drive up the cost of photovoltaics electricity.

This technology is clean and engenders no noise pollution or toxic waste. The silicon is the main raw material used for solar panels, is one of the most abundant substances on Earth (HÄBERLIN, 2012). PV systems involve significant investment, but they do not contain moving parts (except for the inverter) and ideally it has to be maintained between 10 and 15 years.

\section{MATERIAL AND METHOD}

\section{Solar energy and solar PV systems}

Hungary has a good solar potential: every year $1200 \mathrm{kWh} / \mathrm{m}^{2}-1360 \mathrm{kWh} / \mathrm{m}^{2}$ solar energy comes from the sun to the surface of the country. We calculated with $1280 \mathrm{kWh}$ solar energy / year. The Photovoltaic Geographical Information System (www.www.solargis.info, www.re.jrc.ec.europa.eu) is used for these values.

In the summer of 2014 the price / Watt relationship of 8 different solar systems of different performance was compared (types produced for network, fixed onto slanted roof, finished systems, without any unexpected network development (www.napelemdepo.hu). The type 
of solar panels are Renesola, SolarWorld and ET Solar. The brands of inverters are Kaco Powador, SMA and Fronius.

\section{Indicators}

We used dynamic indicators at the calculation as Net present value (NPV), Internal Rate of Return (IRR), Profitability index (PI) and Discounted payback period. The definition of these indicators is not written here because we think this is a basic knowledge of the economy.

\section{RESULTS}

\section{Cost of solar PV systems built in Hungary in 2014}

Household-sized or domestic small power plants (HMKE) (up to 50kVA): In general, a normal household needs less than 10kVA to cover its electricity demand, which means that the capacity of this power plant type fits the needs of small- and medium-sized companies and publicly owned buildings (BOZSOKI EET AL., 2011). In this category we don't have to create energy schedule, so this helps a lot in the spread.

The decline in the price of the finished system is not completely in accordance with capacity of the installed power. Up to $5 \mathrm{kWp}$ decrease can be experienced, over $5 \mathrm{kWp}$ there is a smaller price increase and decrease. The cheapest system regarding the watt / price connection was the $9.8 \mathrm{kWp}$ in 2014 (three-phases, one inverter) (Figure 1).

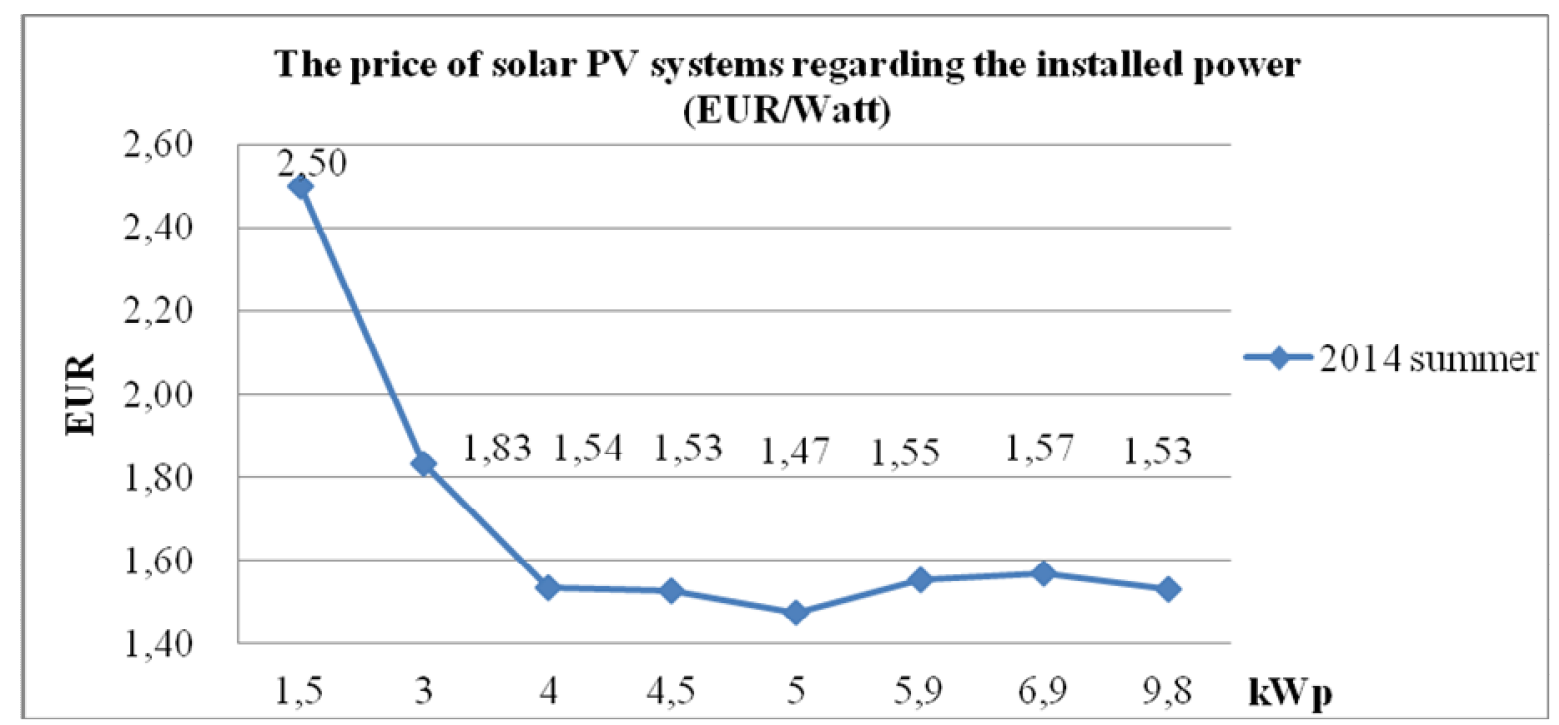

Figure 1. Gross cost of the finished solar PV systems in 2014 summer, depending on the installed capacity (EUR / Watt)

Source: own work based on www.napelemdepo.hu, 2014

The examination of the theoretical payback time of crystalline PV systems, in domestic small power station sizes

We have studied the period of 01.01.2012 - 01.09.2014. In the past there were 4 electricity price reductions for individuals in Hungary (MEKH, 2014). The following table shows the electricity price reductions (Figure 2). During this period the rate of the Hungarian Central Bank was also 
Review on Agriculture and Rural Development 2014. vol. 3 (2) ISSN 2063-4803

decreasing (Table 1). We calculated the payback time with 4 bank rates and we used the current minimum and maximum values (Figure 2).

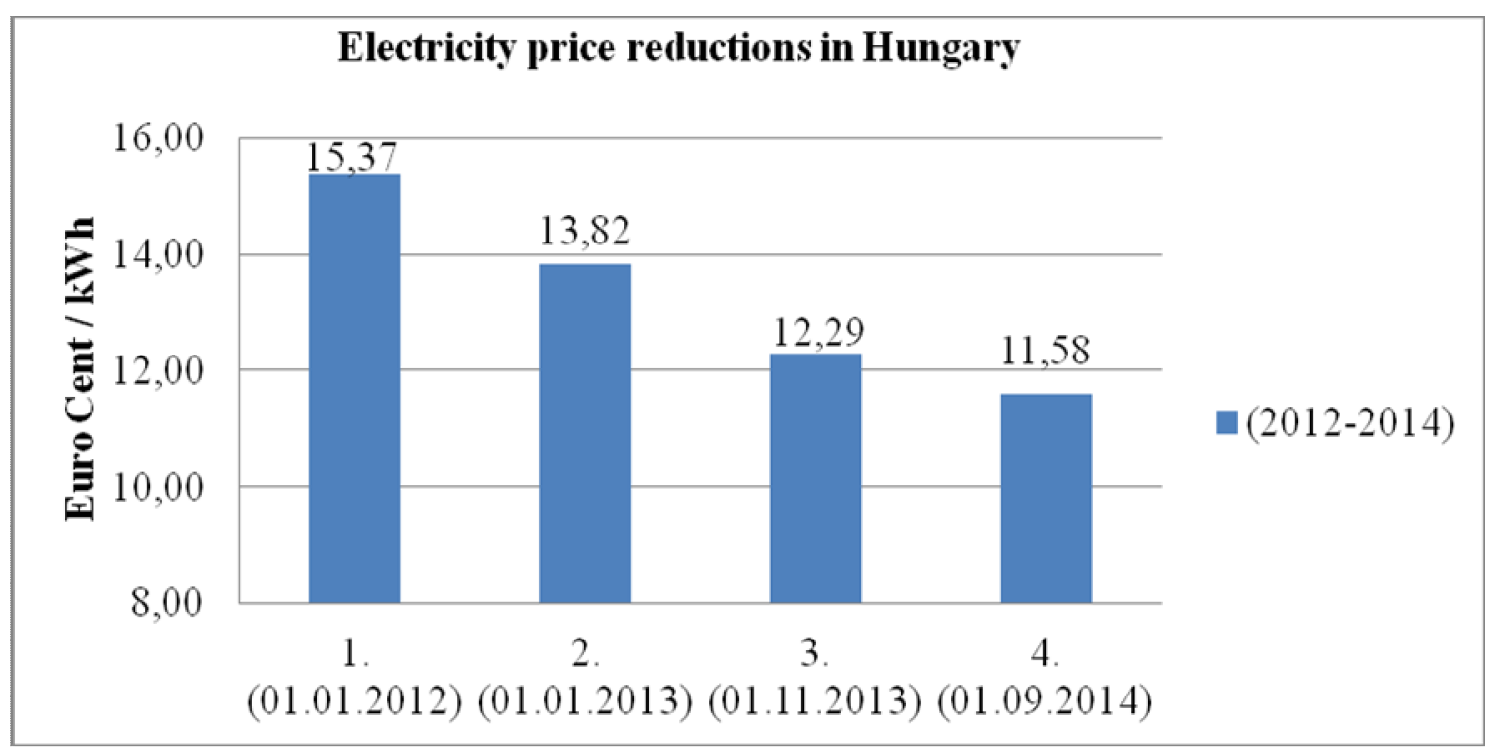

Figure 2. The electricity price reductions for individuals in Hungary

Source: own work based on www.mekh.hu

As Figure 2 shows us, the price of $1 \mathrm{kWh}$ was 15.37 Euro Cent from 01.01.2012 till 01.01.2013. In the period of 01.01.2013 - 01.11.2013 the price was 13.82 then it reduced to 12.29 and it stayed on that level till 01.09.2014. From 01.09.2014 the price of $1 \mathrm{kWh}$ decreased to 11.58 Euro Cent.

We calculated with 4 electricity price reductions and with 305 HUF/EUR exchange rate. Dynamic indicators were used to count the payback period. In the case of a $1 \mathrm{kWp}$ nominal power solar system $1280 \mathrm{kWh}$ were taken into account (www. www.solargis.info, www.re.jrc.ec.europa.eu).

For the energy measurement is need a two-way measuring device. The excess or all energy can be sold to E.ON. A solar power plant should be designed in the current market situation, that it does not produce more energy than it can be used in a given period (Table 2) (www.eon.hu). $4 \mathrm{kWp}$ and $5 \mathrm{kWp}$ solar PV systems were examined assuming $100 \%$ own capital because the authors mentioned that individuals in Hungary had no financial support. These solar PV systems include 1 inverter, which do not require any maintenance for 10-15 years if the instalment is professional and if the inverter is a good quality brand. The average annual physical amortization (sinking of power) was $0.3 \%$ / year at the solar panels based on practical experience, the returns were examined for 15 years (www.napelemdepo.hu, Dirk C. Jordan and Sarah R. Kurtz, 2012). An inverter can be works 10-15 years. The replacement is assumed in 15 years' time. The electricity price increased about 7\% / year between 2000 and 2010. But from 2010 the increase of the price has stopped and the level has stayed at the same place. 
Table 1. Changes of the interest rate

Source: based on www.mnb.hu, 2014

\begin{tabular}{|c|c|}
\hline Years & \% \\
\hline $\mathbf{2 1 . 1 2 . 2 0 1 1 . ~}$ & $\mathbf{7}$ \\
\hline 29.08 .2012$. & 6.75 \\
\hline 26.09 .2012 & 6.5 \\
\hline 31.10 .2012 & 6.25 \\
\hline 28.11 .2012 & 6 \\
\hline $\mathbf{1 9 . 1 2 . 2 0 1 2}$ & $\mathbf{5 . 7 5}$ \\
\hline 30.01 .2013 & 5.5 \\
\hline 27.02 .2013 & 5.25 \\
\hline 27.03 .2013 & 5 \\
\hline 24.04 .2013 & 4.75 \\
\hline 29.05 .2013 & 4.5 \\
\hline 26.06 .2013 & 4.25 \\
\hline 24.07 .2013 & 4 \\
\hline 28.08 .2013 & 3.8 \\
\hline 25.09 .2013 & 3.6 \\
\hline $\mathbf{3 0 . 1 0 . 2 0 1 3}$ & $\mathbf{3 . 4}$ \\
\hline 27.11 .2013 & 3.2 \\
\hline 18.12 .2013 & 3 \\
\hline 22.01 .2014 & 2.85 \\
\hline 19.02 .2014 & 2.7 \\
\hline 26.03 .2014 & 2.6 \\
\hline 30.04 .2014 & 2.5 \\
\hline 28.05 .2014 & 2.4 \\
\hline 25.06 .2014 & 2.3 \\
\hline $\mathbf{2 3 . 0 7 . 2 0 1 4}$ & $\mathbf{2 . 1}$ \\
\hline & \\
\hline
\end{tabular}

We calculated that the reduction of the electricity price has stopped in 2014 and it will have no increase in the next 15 years because any future price increase or decrease gives similar results. Natural damage like lightning or hail were not taken into account.

Table 2. Savings in 1 year in the case of a $1 \mathrm{kWh}$ solar PV system for individuals in Hungary (2012-2014)

Source: own work

\begin{tabular}{|l|c|c|c|c|}
\hline Years & 01.01 .2012 & $\mathbf{0 1 . 0 1 . 2 0 1 3}$ & $\mathbf{0 1 . 1 1 . 2 0 1 3}$ & $\mathbf{0 1 . 0 9 . 2 0 1 4}$ \\
\hline $\begin{array}{l}\text { 1kW solar power plant energy } \\
\text { produced, (kWh) }\end{array}$ & \multicolumn{4}{|c|}{1280} \\
\hline $\begin{array}{l}\text { Electricity supply retail selling price of } \\
\text { electricity in 2014 (Euro Cent/kWh) }\end{array}$ & 15.37 & 13.82 & 12.29 & 11.58 \\
\hline $\begin{array}{l}\text { Overcapacity purchase price in 2014 } \\
\text { (Euro Cent/kWh) }\end{array}$ & 7,07 & 5,92 & 5.06 & 4.49 \\
\hline Savings at 100\% utilization (EUR) & $\mathbf{1 9 6 . 7}$ & $\mathbf{1 7 6 . 9}$ & $\mathbf{1 5 7 . 2}$ & $\mathbf{1 4 8 . 2}$ \\
\hline Savings at 80\% utilization (EUR) & 175.5 & 156.7 & 138.8 & 130.1 \\
\hline Savings at 60\% utilization (EUR) & 154.2 & 136.4 & 120.3 & 111.9 \\
\hline Savings at 0\% utilization (EUR) & $\mathbf{9 0 . 5}$ & $\mathbf{7 5 . 7}$ & $\mathbf{6 4 . 8}$ & $\mathbf{5 7 . 5}$ \\
\hline
\end{tabular}


The results of dynamic indicators

We can see on the Tables 3-6 that the interest rate has influenced the payback period positively while the electricity price reductions increased these values. The two phenomena almost equalized each other. The discounted payback periods were between 27 and 32 years (Tables 3 and 4 ) because the delivery prices were too low with $0 \%$ own utilization.

Table 3. Dynamic indicators analysis with $4 \mathrm{kWp}$ in 15 years, with $0 \%$ own utilization

Source: own work

\begin{tabular}{|c|c|c|c|c|c|c|c|}
\hline Year & 01.01 & .2012 & 01.01 & .2013 & 01.11 & .2013 & 01.09 .2014 \\
\hline System size (kWp) & \multicolumn{7}{|c|}{4} \\
\hline Investment costs (EUR) & \multicolumn{7}{|c|}{6141} \\
\hline Maintenance costs (EUR) & \multicolumn{7}{|c|}{0} \\
\hline $\begin{array}{l}\text { Electricity charge savings, } \\
\text { at the same price (EUR) }\end{array}$ & \multicolumn{2}{|c|}{5316} & \multicolumn{2}{|c|}{4451} & \multicolumn{2}{|c|}{3805} & 3376 \\
\hline$r=$ interest $(\%, \min ; \max )$ & 7 & 5.75 & 5.75 & 3.4 & 3.4 & 2.1 & 2.1 \\
\hline $\begin{array}{l}\text { Present value savings } \\
\text { (EUR) }\end{array}$ & 3240 & 3510 & 2938 & 3448 & 2947 & 3238 & 2873 \\
\hline NPV (EUR) & -2901 & -2631 & $\begin{array}{c}-3 \\
203\end{array}$ & $\begin{array}{c}-2 \\
693\end{array}$ & $\begin{array}{c}-3 \\
194\end{array}$ & -2903 & -3268 \\
\hline IRR (\%) & \multicolumn{2}{|c|}{-1.76} & \multicolumn{2}{|c|}{-3.8} & \multicolumn{2}{|c|}{5.5} & 6.73 \\
\hline PI & 0.53 & 0.57 & 0.48 & 0.56 & 0.48 & 0.53 & 0.47 \\
\hline $\begin{array}{l}\text { Discounted payback period } \\
\text { (Year) }\end{array}$ & (28.4) & $(26.2)$ & (31.4) & (26.7) & (31.3) & (28.4) & (32.1) \\
\hline
\end{tabular}

Table 4. Dynamic indicators analysis with $5 \mathrm{kWp}$ in 15 years, with $0 \%$ own utilization

Source: own work

\begin{tabular}{|c|c|c|c|c|c|c|c|}
\hline Year & \multicolumn{2}{|c|}{01.01 .2012} & \multicolumn{2}{|c|}{01.01 .2013} & \multicolumn{2}{|c|}{01.11 .2013} & 01.09.2014 \\
\hline System size (kWp) & \multicolumn{7}{|c|}{5} \\
\hline Investment costs (EUR) & \multicolumn{7}{|c|}{7370} \\
\hline Maintenance costs (EUR) & \multicolumn{7}{|c|}{0} \\
\hline $\begin{array}{l}\text { Electricity charge savings, } \\
\text { at the same price (EUR) }\end{array}$ & \multicolumn{2}{|c|}{6645} & \multicolumn{2}{|c|}{5564} & \multicolumn{2}{|c|}{4756} & 4220 \\
\hline$r=$ interest $(\%, \min , \max )$ & 7 & 5.75 & 5.75 & 3.4 & 3.4 & 2.1 & 2.1 \\
\hline Present value savings (EUR) & 4050 & 4388 & 3673 & 4310 & 3685 & 4048 & 3592 \\
\hline NPV (EUR) & -3319 & -2982 & -3696 & -3059 & -3685 & -3321 & -3778 \\
\hline IRR (\%) & \multicolumn{2}{|c|}{-1.28} & \multicolumn{2}{|c|}{-3.35} & \multicolumn{2}{|c|}{-5.56} & -6.32 \\
\hline PI & 0.55 & 0.60 & 0.50 & 0.58 & 0.50 & 0.55 & 0.49 \\
\hline $\begin{array}{l}\text { Discounted payback period } \\
\text { (Year) }\end{array}$ & (27.3) & $(\mathbf{2 5 . 2})$ & (30.1) & $(25.6)$ & (30) & $(27.3)$ & (30.8) \\
\hline
\end{tabular}

The discounted payback periods were between 12 and 13 years and the payback period was only 0.7 year worse in 01.09.2014 than in 01.01.2012. 
Table 5. Dynamic indicators analysis with $4 \mathrm{kWp}$ in 15 years, with $100 \%$ own utilization

Source: own work

\begin{tabular}{|c|c|c|c|c|c|c|c|}
\hline Year & \multicolumn{2}{|c|}{01.01 .2012} & \multicolumn{2}{|c|}{01.01 .2013} & \multicolumn{2}{|c|}{01.11 .2013} & 01.09 .2014 \\
\hline System size $(k W p)$ & \multicolumn{7}{|c|}{4} \\
\hline Investment costs (EUR) & \multicolumn{7}{|c|}{6141} \\
\hline Maintenance costs (EUR) & \multicolumn{7}{|c|}{0} \\
\hline $\begin{array}{l}\text { Electricity charge savings, } \\
\text { at the same price (EUR) }\end{array}$ & \multicolumn{2}{|c|}{11562} & \multicolumn{2}{|c|}{10396} & \multicolumn{2}{|c|}{9239} & 8712 \\
\hline$r=$ interest $(\%, \min ; \max )$ & 7 & 5.75 & 5.75 & 3.4 & 3.4 & 2.1 & 2.1 \\
\hline $\begin{array}{l}\text { Present value savings } \\
\text { (EUR) }\end{array}$ & 7046 & 7633 & 6863 & 8054 & 7158 & 7864 & 7415 \\
\hline NPV (EUR) & 905 & 1492 & 722 & 1912 & 1016 & 1723 & 1274 \\
\hline IRR (\%) & \multicolumn{2}{|c|}{9.3} & \multicolumn{2}{|c|}{7.5} & \multicolumn{2}{|c|}{5.65} & 4.76 \\
\hline PI & 1.15 & 1.24 & 1.12 & 1.31 & 1.17 & 1.28 & 1.21 \\
\hline $\begin{array}{l}\text { Discounted payback period } \\
\text { (Year) }\end{array}$ & 13.1 & 12.1 & 13.4 & 11.4 & 12.9 & 11.7 & 12.4 \\
\hline
\end{tabular}

Table 6. Dynamic indicators analysis with $5 \mathrm{kWp}$ in 15 years, with $100 \%$ own utilization

Source: own work

\begin{tabular}{|c|c|c|c|c|c|c|c|}
\hline Year & \multicolumn{2}{|c|}{ 01.01.2012 } & 01.01 & 2013 & \multicolumn{2}{|c|}{01.11 .2013} & 01.09.2014 \\
\hline $\begin{array}{l}\text { System size (kWp) } \\
\end{array}$ & \multicolumn{7}{|c|}{5} \\
\hline Investment costs (EUR) & \multicolumn{7}{|c|}{7370} \\
\hline Maintenance costs (EUR) & \multicolumn{7}{|c|}{0} \\
\hline $\begin{array}{l}\text { Electricity charge savings, } \\
\text { at the same price (EUR) }\end{array}$ & \multicolumn{2}{|c|}{14453} & \multicolumn{2}{|c|}{12995} & \multicolumn{2}{|c|}{11549} & 10890 \\
\hline$r=$ interest $(\%, \min , \max )$ & 7 & 5.75 & 5.75 & 3.4 & 3.4 & 2.1 & 2.1 \\
\hline $\begin{array}{l}\text { Present value savings } \\
\text { (EUR) }\end{array}$ & 8808 & 9542 & 8580 & 10068 & 8948 & 9831 & 9270 \\
\hline NPV (EUR) & 1438 & 2172 & 1209 & 2698 & 1578 & 2461 & 1899 \\
\hline IRR (\%) & \multicolumn{2}{|c|}{10} & \multicolumn{2}{|c|}{8.2} & \multicolumn{2}{|c|}{6.3} & 5.4 \\
\hline PI & 1.2 & 1.29 & 1.16 & 1.37 & 1.21 & 1.33 & 1.26 \\
\hline $\begin{array}{l}\text { Discounted payback } \\
\text { period (Year) }\end{array}$ & 12.6 & 11.6 & 12.9 & 11 & 12.4 & 11.2 & 11.9 \\
\hline
\end{tabular}

We can see the same effect of the bank rate and the electricity price at the Table 5 and 6 because the power is the only different value.

\section{CONCLUSIONS}

The energetic utilisation of solar PV systems, in the size of domestic small power stations (HMKE, $0 \mathrm{kWp}-49.9 \mathrm{kWp}$ ) are increasingly popular in Hungary, because this category is the most profitable with $100 \%$ own utilization. This helps a lot in the spread. The price of 1 
$\mathrm{kWh}$ changed about $27 \%$ from 01.01.2012. to 01.09.2014. During this period the rate of the bank of issue was also decreasing $4.9 \%$ and the two phenomena almost equalized each other. It would be important to rationalize the transfer price of the extra energy like in Western Europe. By the help of this rationalisation could be calculated a more predictable payback period.

According to the authors opinion it is really interesting that despite the sinking energy prices in Hungary the profitability of the solar solar PV systems were not decreasing but it could grow a bit because of the sinking rate of the central bank so becomes a better situation for the solar investments in our country in the period of 2012-2014.

\section{ACKNOWLEDGEMENTS}

Present article was published in the frame of the project TÁMOP-4.2.2.B-15/1/KONV2015-0004 A Pannon Egyetem tudományos mühelyeinek támogatása.

\section{REFERENCES}

HÄBERLIN H., EPPEL H., (2012): Photovoltaics system design and practice. John Wiley \& Sons, Ltd., WILEY. 28 p

Jordan, D.C., Kurtz, S.R. (2012): Photovoltaic Degradation Rates - An Analytical Review NREL is a national laboratory of the U.S. Department of Energy, Office of Energy Efficiency \& Renewable Energy, operated by the Alliance for Sustainable Energy, LLC. $30 \mathrm{p}$.

Bozsoki I., Zane E.B., PobŁocka A., Frank R., BAuknecht D. (2011): Integration of electricity from renewables to the electricity grid and to the electricity market integration National report: Hungary, Berlin, 20 December 2011. 71 p.

REFERENCES RETRIEVED FROM WEBSITES:

- Changes of the bank rate

http://www.mnb.hu/Jegybanki_alapkamat_alakulasa

- Domestic small power stations delivery prices

$\mathrm{http}: / /$ www.eon.hu/Aram_informaciok_arak

- Domestic small power stations information

http://www.eon.hu/eon.php?id=290

- Electricity price reductions (MEKH), 2014

http://www.mekh.hu/kozerdeku-adatok-2/a-magyar-energia-hivatal-kozlemenyei/626-10szazalekkal-csokken-a-lakossagi-villamos-energia-a-foldgaz-es-a-tavho-arajanuartol.html

- Global horizontal irradiation in Hungary http://www.solargis.info/doc/_pics/freemaps/1000px/ghi/SolarGIS-Solar-map-Hungaryen.png

- Photovoltaic Geographical Information System - Interactive Maps http://re.jrc.ec.europa.eu/pvgis/apps4/pvest.php

- Profitability index http://www.absoluteastronomy.com/topics/Profitability_index

- PV prices http://napelemdepo.hu/ 